\title{
PELATIHAN TATA RIAS WAJAH SEHARI-HARI PKK BUKIT BESTARI KOTA TANJUNG PINANG
}

\author{
Dwi Vita Lestari Soehardi ${ }^{1}$, Fitridawati Soehardi ${ }^{* 2}$ \\ ${ }^{1}$ STAI Miftahu'ulum Tanjung Pinang; Jl. Kepondang IV KM.11, Batu IX. \\ *2Program Studi Teknik Sipil, Fakultas Teknik, Universitas Lancang Kuning \\ *E-mail: dwivitalestari@gmail.com, fitridawati@unilak.ac.id*
}

\begin{abstract}
Appearance for women is one way to socialize. Neat, clean and good appearance tends to be treated well by others, especially for women who work are required to give a good appearance in providing services to give a professional impression and provide a comfortable atmosphere for others. This is one aspect that is a concern of the PKK Group in Bukit Bestari District, Tanjung Pinang City, Riau Islands Province. This is the background of community service activities to PKK group members by carrying out makeup training followed by 15 people. This Makeup Training is held with the aim to provide practical knowledge and practice directly using makeup tools especially faces for daily activities. Activities carried out by the method of lecture, discussion, and practice. Based on the results of the training carried out, it showed an increase in the ability of the participants and the enthusiasm of the participants towards this activity. Because this training activity provides the value of knowledge that can be applied in daily work activities, in association and in the household.
\end{abstract}

Keywords: Training, Makeup, PKK

\begin{abstract}
Abstrak
Penampilan bagi wanita merupakan salah satu cara dalam bersosialisasi. Penampilan rapi, bersih dan baik cendrung diperlakukan dengan baik pula oleh orang lain, terutama bagi wanita yang bekerja dituntut harus memberikan penampilan yang baik dalam memberikan pelayanan untuk memberikan kesan professional dan memberikan suasana nyaman bagi orang lain. Hal ini merupakan salah satu aspek yang menjadi perhatian dari Kelompok PKK Kecamatan Bukit Bestari Kota Tanjung Pinang Provinsi Kepulauan Riau. Hal inilah yang melatarbelakangi kegiatan pengabdian kepada masyarakat pada anggota kelompok PKK dengan melaksanakan Pelatihan tata rias diikuti oleh 15 orang. Pelatihan Tata Rias ini diselenggarakan dengan tujuan untuk memberikan pengetahuan praktis dan paraktek langsung menggunakan alat-alat tata rias khususnya wajah untuk kegiatan sehari-hari. Kegiatan dilakukan dengan metode ceramah, diskusi, dan praktek. Berdasarkan Hasil pelatihan yang dilaksanakan menunjukkan peningkatan kemampuan para peserta dan besarnya antusias peserta terhadap kegiatan ini. Karena kegiatan pelatihan ini memberikan nilai pengetahuan yang dapat diterapkan dalam aktivitas pekerjaan sehari-hari, dalam pergaulan maupun di rumah tangga.
\end{abstract}

Kata kunci:Pelatihan, Tata Rias,PKK

\section{PENDAHULUAN}

Penampilan bagi wanita merupakan salah satu cara dalam bersosialisasi. Penampilan rapi, bersih dan baik cendrung diperlakukan dengan baik pula oleh orang lain, terutama bagi wanita yang bekerja dituntut harus memberikan penampilan yang baik dalam memberikan pelayanan untuk memberikan kesan professional dan memberikan suasana nyaman bagi orang lain[1]

Tata rias merupakan cara atau usaha seseorang untuk mempercantik diri khususnya pada bagaian muka atau wajah. Tata rias wajah merupakan suatu seni yang bertujuan untuk mempercantik wajah dengan menonjolkan bagian-bagian yang sudah indah dan menyamarkan atau menutupi kekurangan pada wajah. Rias wajah bertujuan untuk menutupi segala kekurangan dan 
menciptakan ilusi yang menyenangkan pada kulit wajah. Tata rias juga bertujuan untuk menunjang rasa percaya diri seseorang [2].

Pada dasarnya setiap individu memiliki attractiveness (daya tarik) tersendiri pada dirinya. Setiap individu memiliki caranya masing-masing untuk meningkatkan daya tarik. Hal ini dilakukan untuk menimbulkan ketertarikan orang lain terhadap dirinya. Hasil penelitian menunjukkan bahwa terdapat pengaruh penggunaan kosmetik wajah terhadap attractiveness. Foto menggunakan kosmetik wajah memiliki hasil mean attractivenss yang lebih tinggi dibandingkan foto tanpa menggunakan kosmetik wajah [3].

Karyawan atau pekerja perempuan memang sudah selayaknya untuk tetap menjaga penampilan agar menarik. Interaksi antara pegawai dan konsumen lebih hangat dan terasa nyaman, namun penampilan bukanlah penampilan yang tidak berlebihan. Oleh karena penampilan merupakan salah satu penilaian kinerja individu, maka hal ini dapat digunakan pegawai perempuan sebagai kesempatan untuk semakin meningkatkan kualitas kinerja di kantor [4].

Pelatihan Tata Rias dalam Meningkatkan Kemandirian Peserta Didik merupakan bentuk kemandirian yang dapat peserta didik lakukan salah satunya yaitu membuka usaha atau wiarusaha, karena mereka dapat memanfaatkan apa yang telah didapat dari pelatihan yang selama ini mereka ikuti. Pelatihan merupakan salah satu bentuk untuk menjadi seseorang yang dapat memanfaatkan apa yang telah dimiliki, melalui pelatihan peserta didik mampu diberdayakan. Pemberdayaan merupakan salah satu bentuk pembangunan sosial yang menyangkut individu baik dalam artian pemberian Sesuatu yang belum mereka miliki atau didapat[5].

Andrew E.Sikula mengemukakan bahwa pelatihan (training) adalah suatu proses pendidikan jangka pendek yang mempergunakan prosedur sistematis dan terorganisir, pegawai dan non manajerial mempelajari pengetahuan dan keterampilan teknis dalam tujuan yang terbatas. Dengan demikian istilah pelatihan ditunjukan pada pegawai pelaksanaan untuk meningkatkan pengetahuan dan keterampilan teknis[6].

Keanggotaan PKK Kecamatan Bukit Bestari Kota Tanjung Pinang Provinsi Kepulauan Riau terdiri atas ibu-ibu dan para remaja yang mempunyai keanekaragaman tingkat pendidikan dan jenis pekerjaan. Pekerjaan para anggotanya antara lain ibu Rumah Tangga, Karyawan, Pedagang, Pengajar dan Pegawai negeri sipil. Keanekaragaman inilah yang menjadi latar belakang para anggota PKK merasa perlu untuk meningkatkan kemampuan dalam bidang Tata Rias untuk memperbaiki cara berpenampilan menjadi lebih baik.

Berdasarkan permasalahan tersebut kami merasa tertarik untuk membantu para anggota PKK Kecamatan Bukit Bestari Kota Tanjung Pinang Provinsi Kepulauan Riau melalui pengabdian kepada masyarakat cara memberi ilmu dan keterampilan tata rias wajah sehari-hari pada anggota PKK. Hal ini Mengingat anggota PKK hanya memiliki kemampuan merias wajah yang didapat secara otodidak, maka materi dan pelaksanaan keterampilan Tata Rias ini diberikan secara sistematis, artinya pada awal pelaksanaan diberikan pengetahuan tentang fungsi tata rias, jenis kulit wajah dan ciricirinya, berbagai bentuk wajah, kosmetik dan kegunaannya, keserasian antara rias dan busana, serta perlengkapan lainnya. Setelah itu peserta diberikan praktek menggunakan tata rias wajah secara mandiri.

\section{METODE}

Kegiatan pengabdian ini dilakukan untuk meningkatkan kemampuan para ibu-ibu PKK yang mempunyai tingkat pendidikan dan jenis pekerjaan yang berbeda sehingga perlu dicari metode yang sesuia dengan kondisi peserta kegiatan. Metode yang dilakukan dalam pelaksanaan kegiatan ini antara lain

\subsection{Metode Ceramah}

Metode ceramah biasa juga disebut dengan penuturan atau penerangan secara lisan. Melalui "berbicara" sebagai Alat interaksi pada metode ceramah kita dapat memberikan penjelasan dan pengetahuan tentang tahapan-tahapan teori yang harus diketahui dan dimiliki oleh seorang penata rias wajah antara lain seperti pengetahuan berbagai jenis kulit dan ciri-cirinya, pengetahuan bentuk wajah, pengetahuan jenis-jenis kosmetik sesuai dengan jenis kulit dan kegunaannya, serta pelengkapan lainnya yang dibutuhkan dalam melakukan riasan wajah. Hal ini di butuh kan untuk 
memudahkan mereka untuk mengaplikasikan tata rias ke wajah seseorang sesuai jenis kulit dan bentuk wajah sehingga menghasilkan tatarias yang sesuai dengan harapan.

\section{2 Metode Demostrasi}

Metode demostrasi merupakan metode mengajar dengan cara memperagakan benda, kejadian, aturan dan urutan melalui proses kegiatan, baik secara langsung maupun menggunakan menggunakan alat peraga yang cocok dengan pokok bahasan dan materi yang sedang disajikan. Metode demonstrasi adalah metode yang digunakan untuk memperlihatkan suatu proses atau cara kerja suatu benda. Dalam hal ini dilakukan dengan cara memperagakan tahapan-tahapan dimulai dari tata rias wajah untuk sehari-hari dan untuk ke pesta dengan rias wajah

korektif, serta mengkreasikan jilbab disesuaikan dengan bentuk wajah. Peserta dan mempraktekkan semua materi yang diberikan secara berurutan. Metode demostrasi merupakan metode yang efektif dalam pelaksanaan pengabdian ini karena peserta dapat mencoba langsung tentang bagaimana menggunakan tata rias.

\subsection{Metode Evaluasi}

Menurut Anwar membagi waktu evaluasi menjadi dua, yaitu: evaluasi setiap minggu dan evaluasi setiap program berakhir[7]. Metode Evaluasi merupakan metode pengukuran terhadap penilaian hasil evaluasi diri para peserta kegiatan baik secara lisan maupun tulisan. Alat ukur kegiatan berupa kuisioner dan wawancara. Pada kegiatan pengabdian ini seluruh materi yang telah disajikan oleh nara sumber kemudian dipraktekkan kembali oleh masing-masing peserta. Pertemuan berikutnya peserta kembali mempraktekkan secara lengkap terkait dengan materi tata rias wajah yang telah diberikan dengan menggunakan perlengkapan pendukung yang telah disediakan oleh panitia. Pada kegiatan ini akan dilaksanakan evaluasi yang bertujuan untuk mengukur sejauh mana para peserta yang dalam hal ini ibu-ibu PKK Bukit Bestari Kepulauan riau dapat mengerti dan memahami hasil materi materi yang telah disajikan oleh narasumber sebelumnya. Pada tahap evaluasi ini diberikan bimbingan dan arahan yang dapat menambah wawasan mereka tentang tata rias wajah yang sesuai dengan kebutuhan.

\section{HASIL DAN PEMBAHASAN}

Pelaksanaan kegiatan ini melalui beberapa sesi kegiatan yaitu sesi pemberian materi tentang bentuk wajah dan jenis kulit, Tata Rias Wajah dan Alat Kosmetik, Sesi demostrasi dan praktek serta Sesi evaluasi.

\subsection{Sesi Pemberian Materi.}

Pada sesi ini Tutor memberikan materi awal kepada para oeserta tentang pengenalan awal bentuk wajah, jenis kulit, Tata Rias wajah dan Alat-alat kosmetik, hal ini perlu dilakukan agar para peserta mempunyai dasar tentang Tata Rias Wajah itu sendiri. Materi yang disajikan dalam bentuk slide berupa video,foto dan penjelasan ringan sehingga memudahkan para peserta dalam mengerti materi yang disampaikan. Adapun materi yang disampaikan antara lain:

\subsubsection{Materi Bentuk Wajah}

Pengetahuan dasar yang perlu diketahui dalam tata rias adalah mengetahui bentuk wajah karena setia bentuk wajah mempunyai area yang berbeda untuk di ekspos atau ditonjolkan dan kemungkinan ditutupi kekurangnnya dengan menggunakan Make-up. Adapun bentuk-bentuk wajah adalah sebagai berikut[8]:

a. Persegi (Square)

Wajah Persegi mempunyai sisi yang lurus dan hampir tidak ada lengkungan pada rahang, jika dilihat panjang isis rahang kanan ke rahang kiri, kurang lebih panjangnya akan sama dengan panjang dari dagu ke ujung rambut. 


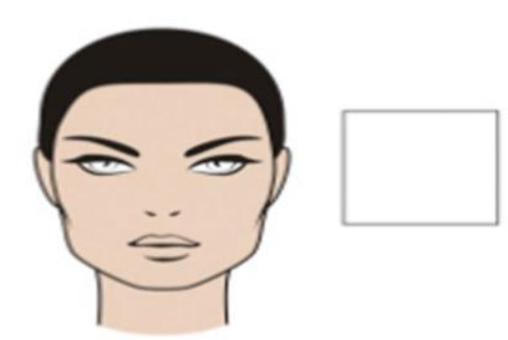

Gambar 1. Bentuk Wajah Persegi

b. Wajik (Diamond)

Wajah Wajik mempunyai dagu yang lancip dan tulang pipi yang tinggi adalah ciri utama dari wajah ini. Jika ditarik garis dari ujung rambut, pipi dan dagu, maka bentuknya akan mirip dengan bentuk wajik. Perbedaan bentuk wajah wajik dan hati adalah dari garis rambut pada wajik cendrung lebih sempit.

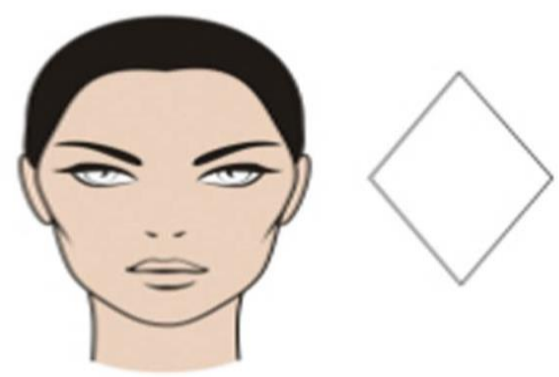

c. Wajah hati (Heart)

Gambar 2. Bentuk Wajah Wajik

Wajah Hati hampir sama dengan wajah wajik, namun wajah hati mempunyai dagu yang lebi lancip. Perbedaan bentuk wajah wajik dan hati adalah wajah hati memiliki dahi yang lebih lebar.
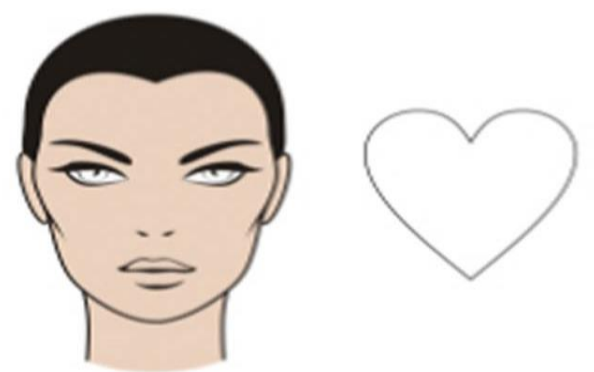

Gambar 3. Bentuk Wajah hati

d. Wajah Segitiga (Rectagular)

Wajah Segitiga mirip dengan wajah Petak pada sisi rahang, namun dagu dan ujung rambutnya lebih panjang.
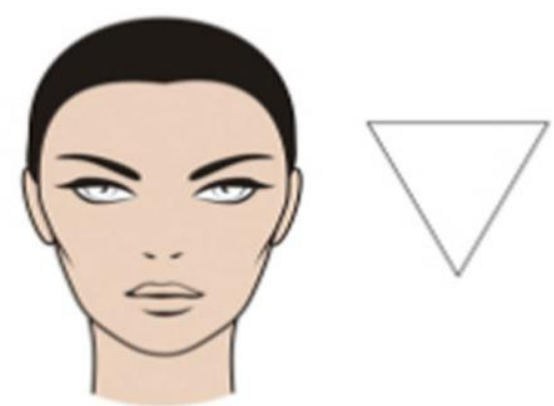

Gambar 4. Bentuk Wajah Segitiga 
e. Wajah Oval

Ciri utama dari wajah oval yaitu lengkungan pada dahi dan dagu, hanya saja lengkungan pada dahi lebih lebar jika dibandingkan pada dagu. Bentuknya hampir mirip wajah Segitiga namun memiliki kurva pada bagian dagu.

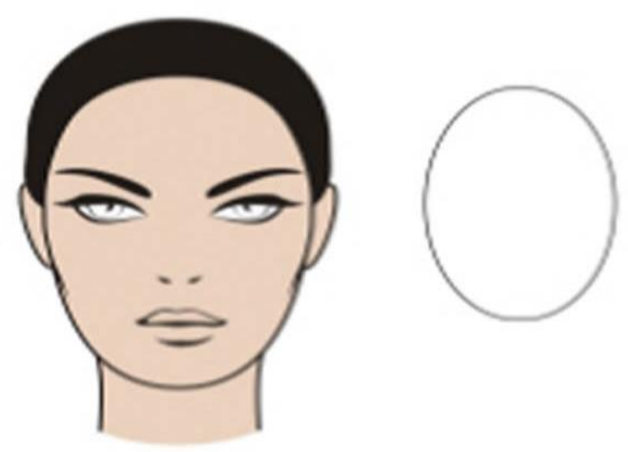

Gambar 5. Bentuk Wajah Oval

f. Wajah Bulat (Round)

Wajah round atau bulat hampir mirip dengan square, hanya saja kedua sisi pada rahangnya membentuk lengkungan, berdagu bulat, dan tulang pipi yang lebar.

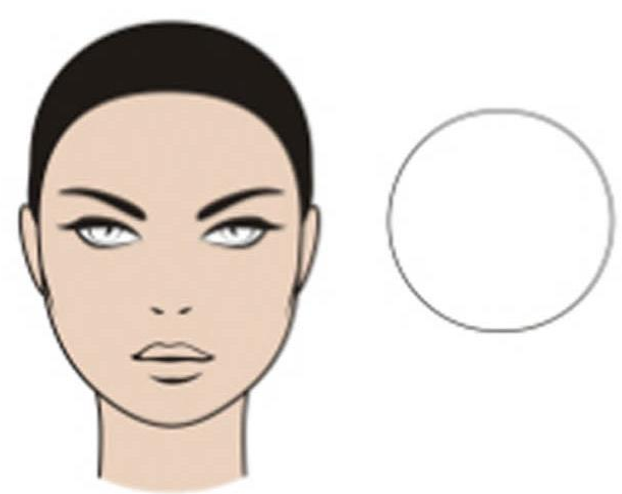

Gambar 6. Bentuk Wajah Bulat

\subsubsection{Materi Jenis Kulit}

Materi ini tentang bagaimana cara mengenali jenis kulit wajah sehingga peserta dapat mengetahui cara menentukan jenis produk perawatan kulit atau make-up yang sesuai jenis kulit wajah. Jenis kulit yang kita miliki sangat bervariasi hal ini tergantung dari beberapa faktor yaitu kadar air karena mempengaruhi kenyamanan kulit dan elatisitasnya, Kadar Minyak karena mempengaruhi kelembutan dan nutrisi pada kulit, dan Tingkat sensitivitas karena akan mempengaruhi toleransi kulit terhadap paparan zat tertentu. Berikut ini adalah beberapa jenis kulit dan ciri-cirinya yang perlu diketahui agar memudahkan peserta dalam memilih produk perawatan kulit dan make-up.

a. Jenis Kulit Normal

Jenis kulit normal memiliki keseimbangan yang baik serta mempunyai kadar air dan minyak yang tepat. Kulit normal memiliki ciri-ciri antara lain hanya memliliki sedikit noda pada wajah, tidak memiliki sensitivitas yang parah terhadap zat tertentu, pori-pori tidak besar, tampak bercahaya.

b. Jenis kulit Kombinasi

Jenis kulit kombinasi bisa jadi kering atau normal dibeberapa area wajah, namun terdapat minyak di area lainnya, pada umumnya area kulit yang berminyak berada di sekitar hidung, dahi dan dagu atu biasa disebut wilayah T-zone. Jenis Kulit Kombinasi Biasanya muncul karena faktor genetic atau factor hormonal yang menyebabkan ketidak seimbangan dalam jumlah serta minyak (lipid) diproduksi. Selain itu Jenis Kulit Kombinasi juga bergantung 
pada cuaca. Beberapa ciri-ciri jenis kulit kombinasi antara lain pori-pori yang terlalu melebar, terdapat komedo, kulit wajah terlihat mengkilap.

c. Jenis Kulit Kering

Jenis kulit sangat cendrung kulit akan menjadi kasar dan bersisik, jenis kulit ini dapat diperburuk oleh beberapa faktor antara lain genetika, proses penuaan atau perubahan horman, cuaca seperti angin,matahari, atau dingin atau ultraviolet (UV) radiasi, pemanas ruangan, berendam atau mandi air hangat yang terlalu lama, bahan atau zat yang terkandung dalam sabun, kosmetik atau agen pembersih dan obat-obatan. Beberapa ciri-ciri jenis kulit kering antara lain pori-pori yang hamper tak terlihat, kulit terlihat kusam dan kasar, terdapat bercak merah, elastisitas kurang, gais-garis halus pada wajah lebih terlihat.

d. Jenis Kulit Berminyak

Jenis kulit berminyak terjadi ketika kelenjar dikulit menegluarkan terlalu banyak minyak (lipid), jenis kuliat berminyak dapat disebabkan atau diperburuk oleh pubertas atau ketidakseimbangan hormaon lainnya, stress, antibiotic, paparan panas, atau terlalu banyak kelembaban. Jenis kulit berminyak dapat berubah tergantung pada usia dan cuaca. Beberapa ciri-ciri jenis kulit berminyak antara lain: pori-pori membesar, kulit terlihat kusam atau mengkilat, kulit tebal, terdapat komedo, bintik-bintik atau noda lainnya.

e. Jenis kulit sensitif

Kulit sensitif biasanya disebabkan oleh berbagai macam faktor, namun biasanya kulit menjadi sensitive karena kontak dngan produk perawatan kulit tertentu. Beberapa ciri-ciri jenis kulit sensitive antara lain kulit menjadi kemerahan, kulit terasa gatal, kulit terasa terbakar, kulit menjadi kering.

\subsubsection{Materi Jenis Tata Rias}

Materi ini tentang produk Tata-Rias dan Alat-alat tata rias yang biasa digunakan dalam melakukan perawatan kecantikan. Hal ini diperlukan agar peserta dapat memahami produk dan peralatan yang digunakan dan tahapan-tahapan dalam proses pelaksanaan tata rias. Adapun materi yang disampaikan antara lain:

a. Produk Tata-Rias

Berikut produk dasar tata-rias yang wajib diketahui dan dimiliki oleh peserta antara lain[9]:

\section{Pelembab}

Pengunaan Pelembab merupakan tahap paling pertama sebelum menggunakan foundation, bedak, dan lain-lain. Tak hanya melindungi kulit wajahmu dari kekeringan parah, pelembap juga bisa mengatur produksi sebum.Pelembap tentu berbeda untuk masing-masing tipe kulit. Pelembap khusus oily skin memiliki formula dan tekstur yang sedikit berbeda dari pelembap khusus kulit kering. Jadi, carilah pelembap atau moisturizer yang sesuai dengan jenis kulitmu. Jika dipakai di pagi hari, pilihlah pelembap yang juga punya perlindungan terhadap sinar UVA dan UVB.

\section{Sunscreeen}

Sunscreen atau tabir surya adalah produk yang jangan pernah kamu lewatkan. Sunscreen penting untuk menjaga wajahmu dari paparan sinar buruk UVA dan UVB. Jika waktumu lebih banyak dihabiskan di dalam ruangan, maka sunscreen dengan SPF 30 sudah cukup. Namun, apabila berada di luar ruangan untuk waktu yang lama, maka pakailah sunscreen dengan SPF 50.

\section{Primer}

Primer dapat menghasilkan makeup yang mulus dan flawless, primer juga membuat pengaplikasikan foundation lebih mudah dan merata. Kelebihan lain yang dimiliki primer adalah meminimalisir pori-pori besar dan kemerah-merahan pada kulit wajah.

\section{Foundation}

Kunci makeup terlihat flawless dan natural adalah pemakaian foundation. Namun, pemilihan foundation yang tepat tidak semudah yang kamu bayangkan. Ada beberapa hal yang patut 
dipertimbangkan, seperti formula dan kecocokkan dengan tone atau warna kulitmu. Salah satu cara tercepat dan teraman untuk mengecek apakah foundation sesuai dengan warna kulitmu atau tidak adalah dengan mengaplikasikannya di wajah atau rahang saat berada di counter makeup. Atau kamu juga bisa bertanya pada penjaga counter atau makeup artist di sana untuk membantumu memilihkan foundation yang benar dan tepat.

\section{Concealer}

Concealer mampu menyembunyikan noda hitam, bekas jerawat, bahkan lingkaran hitam di mata! Concealer diaplikasikan setelah foundation agar makeup menjadi lebih mulus dan sempurna.

\section{Loose Powder (Bedak Tabur)}

Memberi kesan wajah tampak halus dan segar, sehingga mudah membubuhkkan warnah kosmetik

Lainnya

\section{Compact Powder (Bedak Padat)}

Berbentuk sebuk halus dan biasa digunakan sebagai sentuhan akhir pengawet dan penghalus make up.

\section{Eye shadow (pemulas mata)}

Memperindah bentuk mata, mempertajam cahaya mata, memperdalam warnah, sehingga kelihatan bersinar-sinar, dan menormalisisr bentuk mata.

\section{Eye brow pencil (pensil alis)}

Berbentuk padat dengan warna gelap seperti hitam, coklat tua, atau coklat muda, berguna untuk menormalisir bentuk alis serta memperjelas warnanya.

\section{False eye lashes (Bulu Mata Palsu)}

Bulu mata ini dipakai supaya bulu mata kelihatan lebih panjang, lentik, tebal, dan memperjelas warnah bulu mata.

\section{Eye lash adshive (perekat bulu mata)}

Perekat bulu mata ini dipakai untuk melekatkan bulumata pada posisinya.

\section{Eye liner (penggaris mata atau celak mata)}

Menormalisir bentuk mata, dan menutupi tempelan bulu mata palsu.

\section{Eye cream (krim alas pemulas)}

Gunanya untuk melindungi kulit kelopak mata terhadap pengaruh satu warna dan eye shadow, eye liner dan supaya make up mata tahan lama.

\section{Blush On / Blusher and Rouge (Pumulas Pipi)}

Blush On / Blusher warnahnya lebih tua dari pada warnah kulit, gunanya untuk meredupkan atau menyamarkan dan menutupi bagian-bagian wajah yang kurang sempurna. Sedangkan Rouge warnanya merah muda, gunanya untuk memberikan kesan gemuk dan menonjolkan bagian-bagian sempurna.

\section{Lipstik}

Pemilihan lipstik dengan warna dan tekstur yang tepat tidak hanya membuat tampil lebih fresh, tapi juga menghindarkan dari wajah yang kusam dan tak bercahaya. Jenis lipstick tergantung kandungan kandungan minyak didalamnya. 


\section{Milk cleanser (susuh pembersih)}

Membersihkan kotoran dan debuyang lengket pada wajah, sisah make up sampai kelubang poro-pori serta membuat kulit wajah bersih dan halus.

\section{Face Tonik (Penyegar)}

Membersihkan sisah milk cleanser yang lengket pada wajah, mengecilkan poripori, mengencangkan kulit wajah.

b. Alat-alat tata Rias

Materi alat-alat tata rias merupakan hal penting lainnya yang perlu dipelajari, hal ini dikarenakan peralatan inilah yang akan membantu para peserta untuk mengaplikasikan produk kecantikan kepada wajah. Namun setiap peralatan mempunyai fungsinya masingmasing sehingga perlu mengetahui kegunaan masing-masing alat Tatarias antara lain seperti:

1. Saput, biasanya terbuat dari kain halut yang berguna untuk membubukan bedak tabur.

2. Spons bedak, yang gunanya untuk membubukan bedak padat dan juga bisa digunakan secara langsung untuk merapikan kembali. Disamping itu juga spons juga bisa di gunakan untuk menutupi pori-pori dengan cara membasahi spons dengan air terlebih dahulu baru kemudian diberi bedak two cake kemudian disapukan pada wajah.

3. Kuas bedak besar, berfungsi meratakan bedak

4. Sikat alis, meratakan alis agar kelihatan sama penggunaanya sebelum dan sesudah pensil alis.

5. Pencabut alis, membersihkan dan merapikan bulu pada alis.

6. Penjepit bulu mata, berfungsi penjepit buku mata agar lentik

7. Kuas pemulas mata berbentuk kuas spons berfungsi untuk meratakan pemasangan eye shadow.

8. Kuas pemulas pipi, untuk mengusap blush on pada pipi.

9. Kuas Lipstik, untuk mengusap lipstick pada bibir

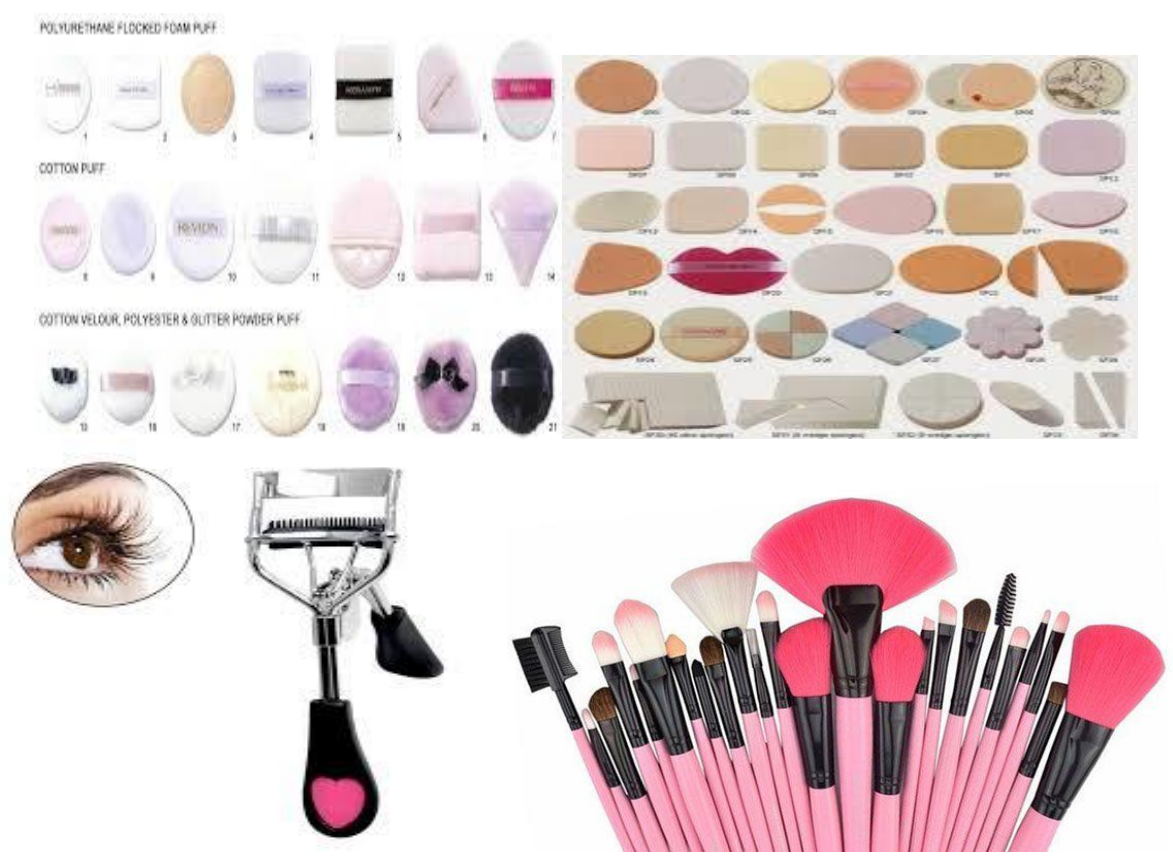

Gambar 7. Alat-alat tata Rias

\subsection{Sesi Demostrasi dan Praktek.}

Sesi berikutnya adalah demostrasi yang dilakukan oleh tutor dengan menggunakan model yang berasal dari salah satu peserta, pada sesi ini tutor menjelaskan dan mempraktekkan langsung materi yang disampaikan sebelumnya tentang bagaimana tata cara dan cara menggunakan produk serta peralatan kosmetik. Demonstrasi yang dilakukan diharapkan dapat memberi kemudahan bagi peserta untuk memahami materi yang disampaikan. Kemudian Para peserta di ajak untuk 
mempraktekkan langsung penggunaan produk dan peralatan kosmetik pada wajah mereka masingmasing. Pada sesi ini juga diberikan waktu untuk sesi diskusi dan sesi tanyajawab tentang materi.umumnya pertanyaan para peserta berkaitan dengan produk makeup dan pemilihan peralatan yang sesuai dengan kondidi kulit dan bentuk wajah mereka. Peserta antusias dalam mempelajari dan mempraktekkan materi yang telah disampaikan.

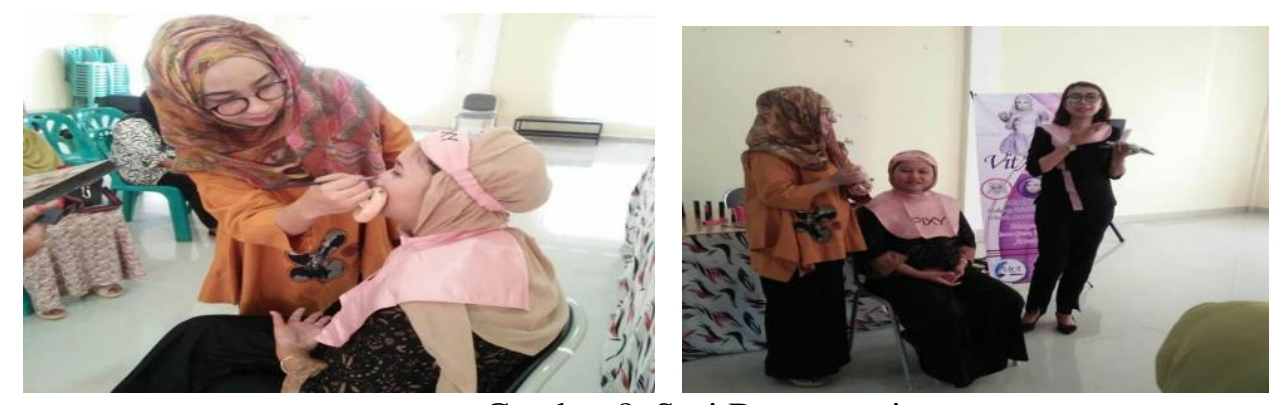

\subsection{Sesi Evaluasi}

Gambar 8. Sesi Demostrasi

Pada sesi ini para peserta dilihat peningkatan kemampuan mereka dari sebelum melakukan pelatihan dan dibandingkan dengan setelah melakukan pelatihan ini. Berdasarkan hasil wawancara, kusioner dan hasil praktek yang dilakukan dapat dilihat bahwa pelatihan ini memberikan hasil yang baik hal ini dapat dilihat dari peningkatan pengetahuan produk dan peralatan Makeup serta kemampuan menggunakan produk dan peralatan makeup pada wajah mereka masing-masing.

Berdasarkan hasil kegiatan ini diharapkan dapat meningkatkan kemampuan para peserta dalam bidang Tata rias. Namun perlu adanya peningkatan materi Jenis Tata Rias lain atau Tata Rias tingkat lanjut yang memerlukan Keahlian yang lebih baik, serta materi bidang fashion dan hijab. Agar dapat memperkaya pengetahuan ibu-ibu PKK Bukit Bestari Kepulauan riau sehingga dengan pelatihan ini diharapkan dapat menambah pengetahuan sehingga dapat dikembangkan menjadi sumber penghasilan yang dapat membantu perekonomian keluarga.

\section{KESIMPULAN}

Kegiatan Pelatihan Tata Rias bagi ibu PKK Bukit Bestari Kepulauan riau mendappatkan apresiasi yang baik dari peserta, berdasarkan hasil evaluasi dapat disimpulkan bahwa terjadi peningkatan pengetahuan para ibu-ibu PKK Bukit Bestari Kepulauan riau terhadap jenis kulit dan bentuk wajah, produk kecantikan, penggunaan alat tata rias. Berdasarkan hasil tersebut diharapkan para ibu-ibu PKK Bukit Bestari Kepulauan riau dapat mengaplikasikan materi yang didapat pada kehidupan sehari-hari mereka sehingga menambah kepercayaan diri mereka. Peserta juga dapat mempergunakan pengetahuan Tata Raias yang didapat sebagai lahan bisnis bagi mereka sehingga dapat menambah pemasukan bagi keluarga mereka.

\section{SARAN}

Kegiatan ini diharapkan ada keberlanjutannya dengan materi-materi Tata Rias lain pengantin atau Tata Rias yang lebih tinggi tingkat kesulitannya. Serta materi cara berpakaian dan penggunaan hijab untuk kebutuhan tertentu, sehingga dapat menambah kemampuan para ibu - ibu PKK Bukit Bestari Kepulauan riau. Kegiatan ini juga perlu adanya pendampingan dari dinas terkait sehingga dapat memberi masukan dan bantuan bagi keberlanjutan pelaksanaan kegiatan seperti ini.

\section{UCAPAN TERIMA KASIH}

Penulis mengucapkan terima kasih kepada ibu-ibu PKK Bukit Bestari Kepulauan riau yang telah berpartisipasi dalam kegiatan ini. Semoga ilmu yang diberikan dapat bermanfaat dan dikembangkan untuk pengembangan diri. 


\section{DAFTAR PUSTAKA}

[1] Efendi,Y.K.2017, Pelatihan Tata Rias Wajah Bagi Tenaga Administrasi Wanita di Lingkungan Universitas PGRI Banyuwangi, Jati Emas ( Jurnal Aplikasi Teknik dan Pengabdian Masyarakat, Vol.1 No.2, Forum Dosen Indonesia( FDI)-DPD Jatim.

[2] D. Purnamasari, 2013, Pelaksanaan Program Keterampilan Tata Rias Sebagai Upaya Memberdayakan Remaja di Panti Sosial Bina Remaja (PSBR), Tridadi, Sleman, Yogyakarta, Skripsi, Program Studi Pendidikan Luar Sekolah, Jurusan Pendidikan Luar Sekolah, Fakultas Ilmu Pendidikan Universitas, Negeri Yogyakarta.

[3] D. F. Herasafitri, U. W. Rahajeng, T. Sarirah, 2016, Wake Up and Make Up: Efek Kosmetik Wajah dan Waktu Pemaparan Terhadap Attractiveness, Mediapsi 2(2): 30-37.

[4] D. R. Rukmawati, I. Dzulkarnain, Konstruksi Kecantikan di Kalangan Wanita Karier (di Kecamatan Lamongan, Kabupaten Lamongan), Prodi Sosiologi FISIB, Universitas Trunojoyo, Madura .

[5] Mega Ida Fatmawati, Model pelatihan Tata Rias Dalam Meningkatkan Kemandirian Peserta Didik Di Lembaga Kursus dan Pelatihan Mutiara Aini, J+Plus Unesa, Volume 2 No.2, Jurnal Mahasiswa Pendidikan Luar sekolah Universitas Negeri Surabaya, Surabaya .

[6] Mangkunegara,A.P. 2006. Perencanaan dan Pengembangan Sumber Daya Manusia. Bandung. PT. Refika Aditama .

[7] Anwar, 2006.Pendidikan kecakapan Hidup ( Life Skill Education). Bandung CV.ALFABETA

[8] Sofi kumala Fatma. 2019. "Bingung dengan bentuk Wajahmu? Ketahui Ciri-cirinya disini", https://www.popbela.com/beauty/make-up/sofi-kumala/bingung-apa-bentuk-wajahmu-ketahuiciri-cirinya-di-sini/full. Diakses Tanggal 9 Mei 2019

[9] Ariata. 2018. "11 Produk Makeup yang wajib dimiliki pemula", https://id.priceprice.com/kecantikan/news/11-Produk-Makeup-yang-Wajib-Dimiliki-Pemula6837/. Diakses tanggal 10 Mei 2019

[10] Yuli Kartika. 2017. Pelatihan Tata Rias wajah bagi Tenaga Administrasi Wanita di Lingkungan Universitas PGRI Banyuwangi. Jurnal Jati Emas Volume 1 No.2 Oktober, Forum Dosen Indonesia FDI-DPD Jawa Timur. 